\begin{tabular}{|l|l|l|}
\hline \multicolumn{2}{|c|}{ PublisherInfo } \\
\hline \hline PublisherName & $:$ & BioMed Central \\
\hline \hline PublisherLocation & $:$ & London \\
\hline \hline PublisherImprintName & $:$ & BioMed Central \\
\hline \hline
\end{tabular}

\title{
Alternate cell-death program identified
}

\begin{tabular}{|l|c|l||}
\hline \multicolumn{2}{|c|}{ ArticleInfo } \\
\hline \hline ArticleID & $:$ & 5090 \\
\hline \hline ArticleDOI & $:$ & $10.1186 /$ gb-spotlight-20050603-01 \\
\hline \hline ArticleCitationID & $:$ & spotlight-20050603-01 \\
\hline \hline ArticleSequenceNumber & $:$ & 66 \\
\hline \hline ArticleCategory & $:$ & Research news \\
\hline ArticleFirstPage & $:$ & 1 \\
\hline \hline ArticleLastPage & $:$ & 3 \\
\hline \hline & & RegistrationDate : 2005-6-3 \\
\hline ArticleHistory & $:$ & OnlineDate \\
\hline \hline ArticleCopyright & $:$ & BioMed Central Ltd2005-6-3 \\
\hline \hline ArticleGrants & $:$ & \\
\hline \hline ArticleContext & $:$ & 130596611 \\
\hline \hline
\end{tabular}


Melissa Lee Phillips

Email: mlp@nasw.org

Although research over the past decade has shown that apoptosis is likely not the only type of programmed cell death, little is known about what other mechanisms may look like. In this week's onlineNature Chemical Biology, Junying Yuan at Harvard University and her colleagues reveal such a pathway by identifying a chemical that blocks nonapoptotic programmed cell death, both in vitro and in a mouse model of ischemic brain injury.

The paper shows that the chemical, Nec-1, has no effect on apoptosis - only on this programmed necrosis-like death, which Yuan and her colleagues term "necroptosis." The researchers also show that although necroptosis shows some characteristics of autophagy, this is a downstream consequence of necroptotic signaling, not an upstream effector of it.

"There have been many hints that there are ways to kill cells" other than the classical apoptotic pathway, Shai Shaham, of the Rockefeller University, told The Scientist. "The one thing that has been lacking so far has been a way to figure out what proteins are involved in these other pathways."

A canonical apoptotic pathway is triggered when ligands bind to members of the Fas/TNFR (tumor necrosis factor receptor) family of death-domain receptors. This pathway sequentially turns on multiple caspases, which are cysteine proteases that effect apoptotic cell death. Some work has shown, however, that the Fas/TNFR family can induce cell death even when caspase signaling - and therefore apoptosis is inhibited. Also, cell death under these conditions usually looks more like necrosis than apoptosis.

"There are a number of forms of programmed cell death that have been identified that have more necrotic-like phenotypes," said Alan Faden, of Georgetown University Medical Center.

What's been missing, according to Yuan, is proof that a common pathway carries out nonapoptotic programmed cell death in the multiple types of cells in which it's been observed. "So we asked the question: Can we find a chemical that inhibits all of those cell deaths?" Yuan told The Scientist.

Yuan and her colleagues screened a chemical library of about 15,000 compounds, looking for inhibitors of an alternate death pathway. When human cells were treated with tumor necrosis factor- $\alpha, a$ ligand for the Fas/TNFR family, along with a pan-caspase inhibitor, many cells died a necrosis-like death, as expected. They found one small molecule, however, that prevented these cells from dying.

The researchers tested this chemical, which they name necrostatin-1, or Nec-1, in many different types of cells and found that it inhibited TNFa-induced necrosis in all of them. This is the first direct evidence of a common, alternative form of programmed cell death, Yuan said.

"They've described what appears to be a novel pathway," Faden told The Scientist. "It's extremely well done work."

Yuan and her coworkers also wanted to see if they could find evidence of necroptosis in vivo, since it's well known that ischemic brain injury, such as that seen in stroke, involves both apoptotic and nonapoptotic programmed cell death, Yuan said. 
The researchers found that injecting necrostatin-1 into mouse ventricles significantly reduced the volume of dead brain tissue after stroke-like injury. This protection suggests that necroptosis is involved in this form of pathologic cell death, the authors say.

The paper is consistent with other studies showing "that the complexities of cell death are much more varied than we had imagined a half dozen years ago," Faden told The Scientist. The next step, he said, is to use necrostatin- 1 to identify the components of the signal transduction cascade responsible for necroptosis.

Shaham is not completely convinced that necroptosis is separate from known cell-death pathways. "The way to make it solid is to find the components of that pathway and show that they have killing activity," he said. "That's why I like this paper - because it finally gives you a clue of how to do that."

\section{References}

1. A.G. Yakolev, A.I. Faden, "Mechanisms of neural cell death: Implications for development of neuroprotective treatment strategies," Neurorx, 1:5-16, January 2004.

2. A. Degterev et al., "Chemical inhibitor of nonapoptotic cell death with therapeutic potential for ischemic brain injury," Nat Cell Biol, DOI:10.1038/nchembio711, May 29, 2005., [http://www.nature.com/nchembio/]

3. Junying Yuan, [http://cellbio.med.harvard.edu/faculty/yuan/]

4. Shai Shaham, [http://www.rockefeller.edu/labheads/shaham/shaham-lab.php]

5. H. Matsumura et al., "Necrotic death pathway in Fas receptor signaling," J Chem Biol, 151:1247-56, December 11, 2000.

6. Alan I. Faden, [http://www.neuro.georgetown.edu/faden.htm]

7. E.H. Lo et al., "Mechanisms, challenges and opportunities in stroke," Nat Rev Neurosci. 4:399-415, May 2003. 